\title{
Proteolysis of ovine and caprine caseins in solution by enzymatic extracts from flowers of Cynara cardunculus
}

\author{
M. José Sousa and F. Xavier Malcata \\ Escola Superior de Biotecnologia, Universidade Católica Portuguesa, Porto, Portugal
}

\begin{abstract}
Primary proteolysis of ovine and caprine $\mathrm{Na}$-caseinate at $30^{\circ} \mathrm{C}$ in phosphate buffer at pH 6.5 or 5.5 in the absence of $\mathrm{NaCl}$ and at $\mathrm{pH} 5.2$ with $5 \%(\mathrm{w} / \mathrm{v}) \mathrm{NaCl}$ by cardosins in aqueous extracts of Cynara cardunculus flowers was investigated using urea-polyacrylamide gel electrophoresis and reversed-phase high performance liquid chromatography. Caprine caseinate underwent more extensive degradation than ovine caseinate under the same conditions ( $p H 6.5$ and pH 5.5); proteolysis of $\beta$ - and $\alpha_{s}$-caseins in ovine and, to a lesser extent, in caprine caseinates was reduced in the presence of $5 \%(w / v) ~ N a C l$. Peptide profiles of the pH 4.6-soluble extract had different patterns throughout ripening arising from the different specificity of cardosins toward ovine and caprine Na-caseinates. The major cleavage sites in ovine (caprine) caseinate were Phe105-Met106 (Lys116-Thr117) for к-casein, Leu127-Thr128 and Leu190-Tyr191 (Glu100-Thr101, Leu127-Thr128, Leu136-Prol37 and Leu190Tyr191) for $\beta$-casein, Phe ${ }_{23}-$ Val $_{24}\left(\right.$ Phe $_{23}$-Val $_{24}$, Trp164-Tyr165 and Tyr173-Thr174) for $\alpha_{s 1}$-casein and Phe88-Tyr89 (Ser9-Ser10, Phe88-Tyr89 and Tyr179-Leu180) for $\alpha_{s 2}$-casein. (C) 1998 Elsevier Science Inc.
\end{abstract}

Keywords: plant rennet, cheese ripening, proteases, enzyme specificity

\section{Introduction}

One of the most successful rennets of plant origin, as apparent from long term use in Portugal for the manufacture of farm cheeses from ovine milk, is obtained from the flowers of the thistle, Cynara cardunculus L. ${ }^{1}$

An acid proteinase was first isolated from dried thistle flowers by Faro et $\mathrm{al}^{2}$ and shown to induce milk clotting via cleavage of the sensitive bond Phe105-Met106 in bovine к-casein. ${ }^{3,4}$ The aqueous extract of flowers of $C$. cardunculus was further shown to possess three active proteinases (once termed cynarases or cyprosins, and currently termed cardosins) which have been isolated, purified and partly characterized in terms of activity ${ }^{5-8}$ and specificity $4,9,10$ toward pure bovine caseins. More recently, two additional aspartic proteinases were isolated from the fresh stigmae of a standard variety of $C$. cardunculus L. Based on the structural and kinetic properties of these enzymes, it was

Address reprint requests to Dr. F. X. Malcata, Universidade Catolica Portuguesa, Escola Superior de Biotecnologia, Rua Dr. Antonio Bernardino de Almeida, P-4200 Porto, Portugal

Received 25 March 1997; revised 21 July 1997; accepted 5 August 1997 concluded that they result from different genes and are different from the previously reported proteinases of the same plant; hence, they were named cardosin $\mathrm{A}$ and cardosin B. ${ }^{11,12}$ Each cardosin consists of two subunits with apparent molecular weights of 31 and $15 \mathrm{kDa}$ for cardosin $\mathrm{A}$ and 34 and $14 \mathrm{kDa}$ for cardosin B. ${ }^{12,13}$ Specificity and kinetic studies were performed using the $\beta$-chain of oxidized insulin. ${ }^{3}$ Taking advantage of the derived chromophoric peptides, it was reported that cardosin $\mathrm{A}$ is similar to chymosin whereas cardosin B resembles pepsin. ${ }^{13,14}$

Although considerably less susceptible than the Phe105Met106 bond of $\kappa$-casein, peptide bonds of $\alpha_{\mathrm{s}^{-}}, \alpha_{\mathrm{s} 2^{-}}$, and $\beta$-caseins are also hydrolyzed by cardosins (and by chymo$\sin$ ) if subject to appropriate environmental conditions. The susceptibility of bovine $\mathrm{Na}$-caseinate to proteolysis is strongly influenced by the state of aggregation of the substrate $^{15}$ which is in turn affected by $\mathrm{pH}$ and $\mathrm{NaCl}$. Fundamental information on the action of cardosins on ovine and caprine milks is scarce, and straightforward extrapolation of conclusions obtained with pure bovine caseins to ovine and caprine counterparts is risky. In fact, unlike bovine caseins, ovine caseins exhibit two groups of electrophoretic bands. The group with lower mobility contains $\beta$-casein and is divided into two variants, $\beta_{1^{-}}$and 
$\beta_{2}$-casein, which differ in the level of phosphorylation (6 and 5 , respectively), ${ }^{16}$ although levels ranging continuously from 1-7 have also been reported. ${ }^{17}$ The group with higher mobility consists of three bands $\left(\alpha_{\mathrm{s}^{-}}, \alpha_{\mathrm{s}^{2}}\right.$ and $\alpha_{\mathrm{s} 3^{-}}$-caseins), designated as a whole as $\alpha_{\mathrm{s}}$-casein region despite the microheterogeneity arising from variations in the degree of glycosylation and/or phosphorylation coupled with genetic polymorphism. ${ }^{18-21}$

The scope of this work was to experimentally monitor the evolution with time of the breakdown patterns of ovine and caprine caseins by cardosins in crude aqueous extracts of $C$. cardunculus using experimental conditions that parallel milk (pH 6.5) and cheese at early stages of ripening in the absence of salting (pH 5.5) or at early stages of ripening with $5 \% \mathrm{NaCl}(\mathrm{w} / \mathrm{v})(\mathrm{pH} 5.2)$ with the goal of furthering knowledge on the nature of action of this plant rennet in cheesemaking and ripening.

\section{Materials and methods}

\section{Enzyme}

Dried flowers of the wild thistle (C. cardunculus L.) were obtained in the Serra da Estrela region (Portugal). The crude extract was prepared by grinding the stigmae of the flowers for $36 \mathrm{~s}$, homogenizing in $0.1 \mathrm{M}$ citrate buffer at $\mathrm{pH} 5.9$, and centrifuging at 12,000 $g$ for $5 \mathrm{~min}$. The crude extract $\left(0.1 \mathrm{~g}\right.$ of ground flowers $\mathrm{ml}^{-1}$ buffer) had a protein concentration of $4.54 \mathrm{mg} \mathrm{ml}^{-1}$ as determined by the Coomassie spectrophotometric method using bovine serum albumin as standard.

\section{Milk clotting activity}

Rennet clotting activity was measured using low-heat skim milk powder NILAC ${ }^{\mathrm{TM}}$ (NIZO, Ede, The Netherlands); the milk substrate was prepared by dissolving $12 \mathrm{~g}$ in $100 \mathrm{ml}$ of $10^{-2} \mathrm{M} \mathrm{CaCl}_{2}$ (pH 6.5) at $30^{\circ} \mathrm{C}$ and $2 \mathrm{ml}$ of this substrate were mixed with $0.2 \mathrm{ml}$ of crude enzyme extract. One rennet unit (RU) was defined as the amount of crude enzyme extract needed to coagulate $10 \mathrm{ml}$ of milk substrate at $30^{\circ} \mathrm{C}$ in $100 \mathrm{~s}$.

\section{Substrate}

Whole ovine and caprine caseins were prepared via isoelectric precipitation of ovine and caprine milks, respectively, by acidification to $\mathrm{pH} 4.2-4.3$ with $6.0 \mathrm{M} \mathrm{HCl}$, heating to $37^{\circ} \mathrm{C}$ for $30 \mathrm{~min}$ and centrifugation at $6,000 \mathrm{~g}$ for $10 \mathrm{~min}$. The precipitate was recovered by filtration and washed several times with distilled water. The caseins were dispersed in distilled water, the $\mathrm{pH}$ adjusted to 7.0 with $\mathrm{NaOH}$ and the system allowed to equilibrate for at least $3 \mathrm{~h}$ at $4^{\circ} \mathrm{C}$ before lyophilization.

\section{Hydrolysis of caseins}

Ovine and caprine Na-caseinates were dissolved in $100 \mathrm{~mm}$ phosphate buffer at $\mathrm{pH} 6.5$ or $\mathrm{pH} 5.5$, or at $\mathrm{pH} 5.2$ in the presence of $5 \% \mathrm{NaCl}$, to a final concentration of $10 \mathrm{mg} \mathrm{ml}^{-1}$. The crude enzyme extract $\left(0.270 \mathrm{RU} \mathrm{ml}^{-1}\right)$ was then added at a ratio of 0.526 $\mathrm{ml}$ to $10 \mathrm{ml}$ of caseinate $(\mathrm{v} / \mathrm{v})$ and the experimental solutions (together with appropriate controls at each $\mathrm{pH}$ and salt concentration) were held at $30^{\circ} \mathrm{C}$ in a thermostated water bath. Aliquots were taken at $1 \mathrm{~min}, 30 \mathrm{~min}, 1 \mathrm{~h}, 3 \mathrm{~h}, 6 \mathrm{~h}, 12 \mathrm{~h}$ and $24 \mathrm{~h}$. Samples for urea-polyacrylamide gel electrophoresis were mixed with the sample buffer containing mercaptoethanol and urea to inactivate the enzyme and unfold the protein, whereas those for reversed- phase high performance liquid chromatography were heated at $85^{\circ} \mathrm{C}$ for $30 \mathrm{~min}$ to inactivate the enzyme.

\section{Urea polyacrylamide gel electrophoresis (Urea-PAGE)}

Samples $(0.75 \mathrm{ml})$ of hydrolysates, obtained and quenched as described above, were prepared for urea-PAGE by adding an equal volume of double-concentrated sample buffer. ${ }^{22}$ Urea-PAGE was performed using a Protean II XI vertical slab-gel unit (Bio-Rad Laboratories, Watford, UK) according to the method of Andrews ${ }^{36}$ $(12.5 \% \mathrm{~T}$-acrylamide plus bisacrylamide, $4 \% \mathrm{C}$-bisacrylamide as a percentage of $\mathrm{T}$ ) at $\mathrm{pH} 8.9$, with modifications, ${ }^{23}$ the gels were stained with Coomasie Blue G-250 (Bio-Rad, Richmond CA) using the method of Blakesley and Boezi. ${ }^{24}$ Quantification of intact $\beta_{1^{-}}, \beta_{2^{-}}, \alpha_{\mathrm{s} 1^{-}}, \alpha_{\mathrm{s} 2^{-}}$and $\alpha_{\mathrm{s} 3^{-}}$-caseins was by densitometry using a model CD60 densitometer (Desaga, Sarstedt-Gruppe, Germany).

\section{Reversed-phase high performance liquid chromatography (RP-HPLC)}

Samples of hydrolysates $(2 \mathrm{ml})$, obtained and quenched as described above, were adjusted to $\mathrm{pH} 4.6$ by addition of $60 \mu \mathrm{l}$ of $33.3 \%(\mathrm{w} / \mathrm{v})$ acetic acid, held at room temperature for $10 \mathrm{~min}$ and then $60 \mu \mathrm{l}$ of $3.33 \mathrm{~m}$ sodium acetate added. ${ }^{25}$ The samples were centrifuged at $6,000 \mathrm{~g}$ for $10 \mathrm{~min}$ and the supernatants recovered for analysis. RP-HPLC was performed by the method of Singh et $a l .{ }^{26}$ using a Beckman system (Beckman Instruments, San Ramon CA). A Lichrosorb RP-8 $(5 \mu \mathrm{m}) 250 \times 4 \mathrm{~mm}$ column (Merck, Darmstadt, Germany) was employed with an Lichrocart 4-4 guard column (Merck). Elution was at $30^{\circ} \mathrm{C}$ using a mobile phase of two solvents: A ( $0.1 \%$ trifluoroacetic acid in water) and B $(0.1 \%$ trifluoroacetic acid in acetonitrile) at a flow rate of $1.0 \mathrm{ml} \mathrm{min}{ }^{-1}$ starting with $100 \%$ A for $5 \mathrm{~min}$ and then a linear gradient for 55 min up to $50 \% \mathrm{~B}$, holding at $50 \% \mathrm{~B}$ for $6 \mathrm{~min}$, a linear gradient for $4 \mathrm{~min}$ up to $60 \% \mathrm{~B}$ and finally holding at $60 \% \mathrm{~B}$ for $3 \mathrm{~min}$. Absorbance of the eluate was read at $214 \mathrm{~nm}$. Samples $(10 \mathrm{mg}$ $\mathrm{ml}^{-1}$ ) were dissolved in a mixture of solvents A and B (1: 0.01 , $\mathrm{v} / \mathrm{v})$, filtered through $0.22 \mu \mathrm{m}$ cellulose acetate filter and an aliquot $(75 \mu \mathrm{l})$ of the permeate was injected.

\section{Isolation of peptides}

Peptides were isolated by RP-HPLC as described above or by electroblotting from urea-PAGE gels using a mini Trans-Blot ${ }^{\mathrm{TM}}$ electrophoretic transfer cell (Bio-Rad, Hercules CA). In the latter case, transfer of peptides was at $100 \mathrm{~V}$ for $30 \mathrm{~min}$ in 10 mM CAPS (3-cyclohexylamino-1-propanesulfonic acid) buffer with $10 \%$ methanol onto polyvinylidene difluoride membranes (PVDF) with a pore size of $0.22 \mu \mathrm{m}$ (Bio-Rad). Membranes were rinsed with water and stained in $0.2 \%$ Ponceau $\mathrm{S}$ in $1 \%$ acetic acid for $1 \mathrm{~min}$ followed by destaining in water. Bands corresponding to peptides were excised from the membranes and sequenced (5-10 cycles).

\section{Sequence analysis}

Peptides were sequenced at the National Food Biotechnology Centre, University College Cork via Edman degradation on an automated pulsed liquid-phase protein-peptide sequencer (Applied Biosystems model 477A, Foster City CA). Liberated amino acids were detected as their phenylthiohydantoin derivatives. 


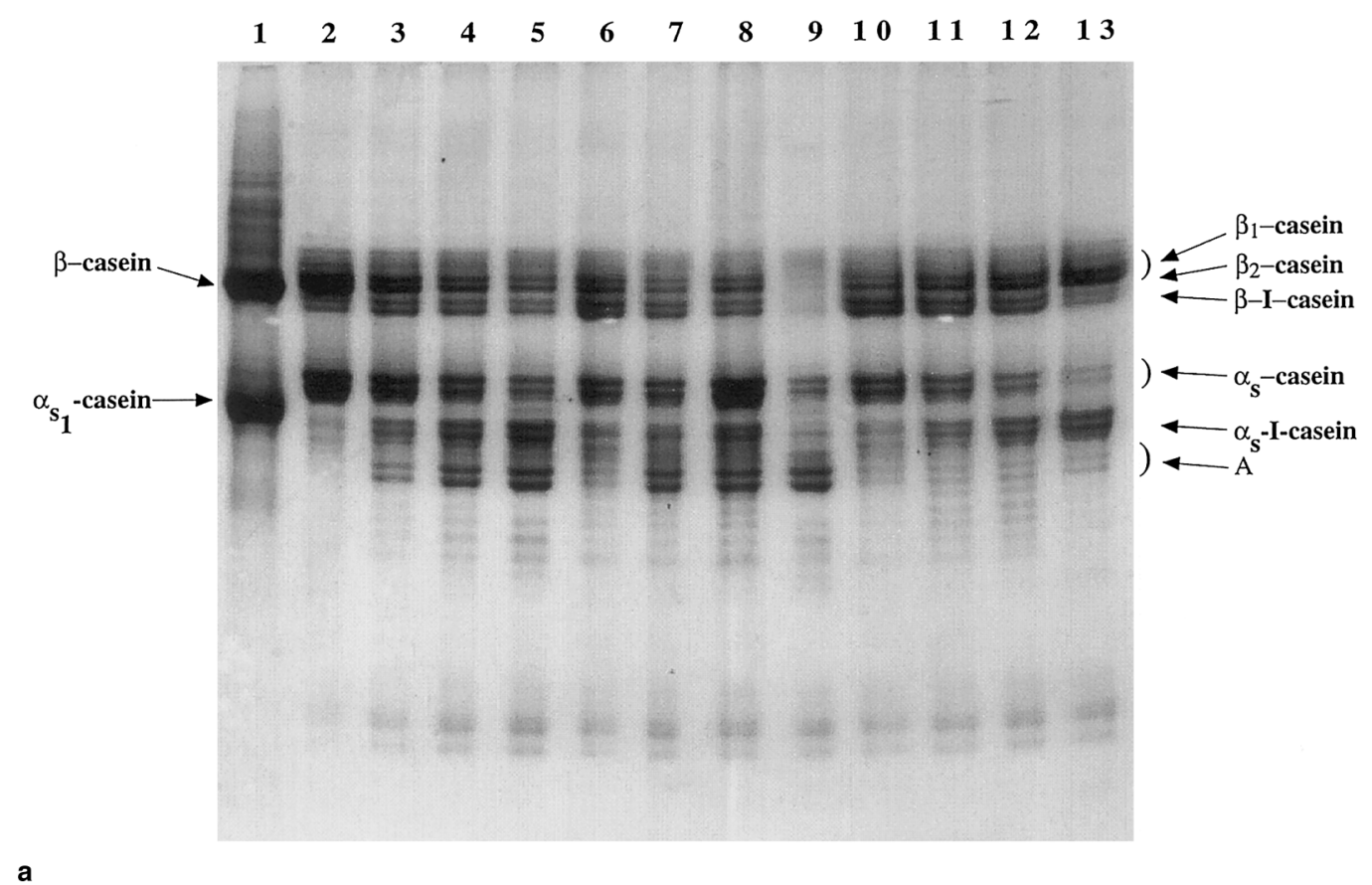

a

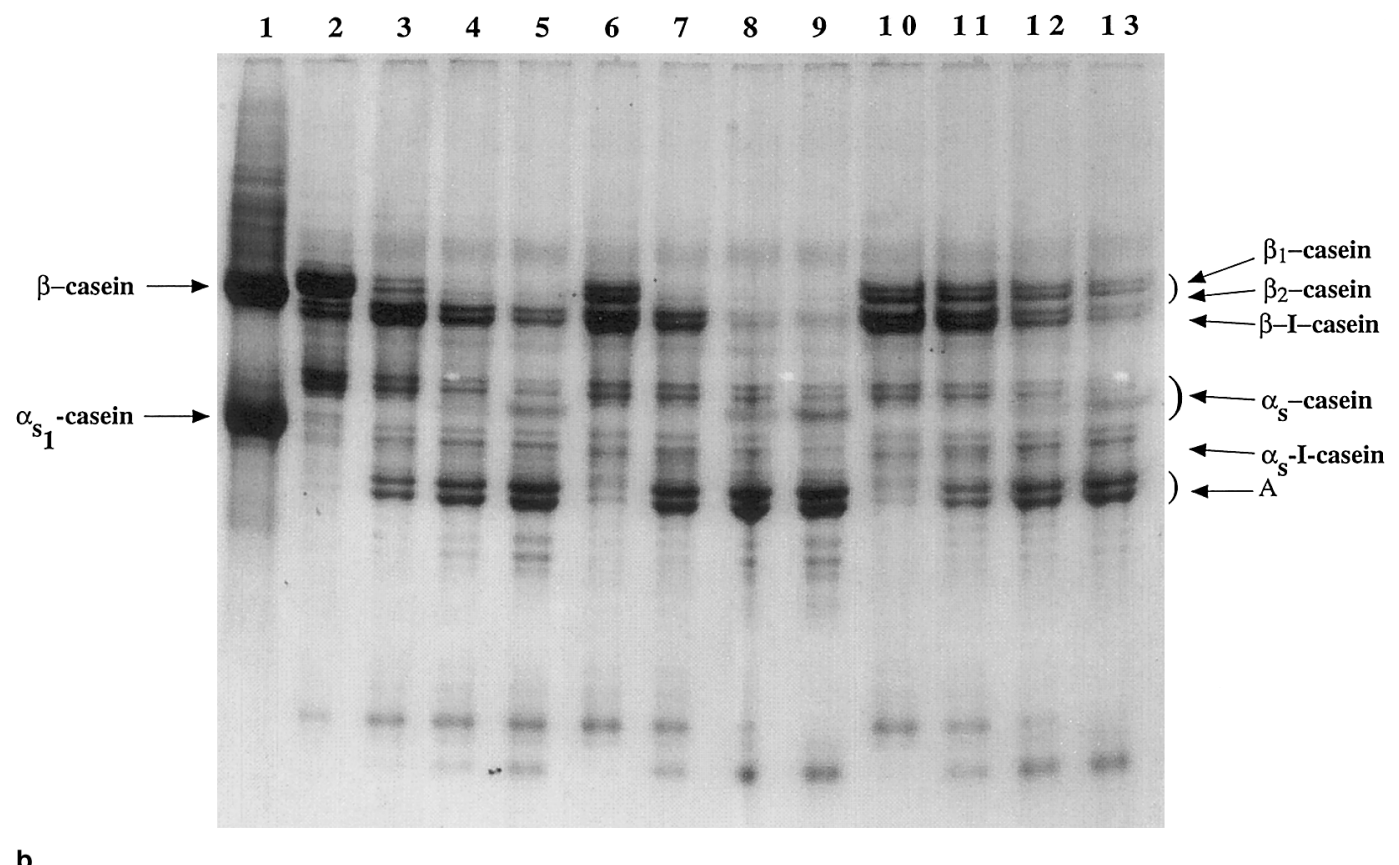

Figure 1 Urea-PAGE electrophoregrams of ovine Na-caseinate (a) and caprine Na-caseinate (b) hydrolyzed by extracts of $C$. cardunculus at $30^{\circ} \mathrm{C}$ and $\mathrm{pH} 6.5$ (lanes 2-5), $\mathrm{pH} 5.5$ (lanes $6-9$ ), and $\mathrm{pH} 5.2$ with $5 \%(\mathrm{w} / \mathrm{v}) \mathrm{NaCl}$ (lanes $10-13$ ) for $1 \mathrm{~min}, 1 \mathrm{~h}, 3 \mathrm{~h}$ and $6 \mathrm{~h}$ respectively. Bovine $\mathrm{Na}$-caseinate was included as standard in lane 1 of both (a) and (b)

\section{Results and discussion}

\section{Experimental data}

Urea-PAGE electrophoregrams of ovine and caprine $\mathrm{Na}-$ caseinates hydrolyzed by extracts of $C$. cardunculus $(0.0142$ $\mathrm{RU} \mathrm{m} \mathrm{m}^{-1}$ ) at $\mathrm{pH} 6.5, \mathrm{pH} 5.5$, and $\mathrm{pH} 5.2$ with $5 \% \mathrm{NaCl}$ $(w / v)$ throughout the hydrolysis time are shown in Figures $1 a$ and $1 b$. As expected, the extent of degradation of $\beta$ - and $\alpha_{\mathrm{s}}$-caseins in both ovine and caprine Na-caseinates depended on ionic strength and $\mathrm{pH}$. Ovine $\mathrm{Na}$-caseinate at $\mathrm{pH}$ 6.5 or 5.5 (Figure 1a, lanes 2-8) showed similar rates of hydrolysis of $\beta$-caseins $\left(\beta_{1}\right.$ - and $\beta_{2}$-casein) and $\alpha_{\mathrm{s}}$-caseins for $3 \mathrm{~h}$ of hydrolysis; however, $\beta$-casein was almost completely degraded in all cases whereas $\alpha_{\mathrm{s}}$-caseins showed only extensive degradation at $\mathrm{pH} 5.5$ by $6 \mathrm{~h}$ of hydrolysis (Figure la, lane 9). Caprine Na-caseinate exhibited more 

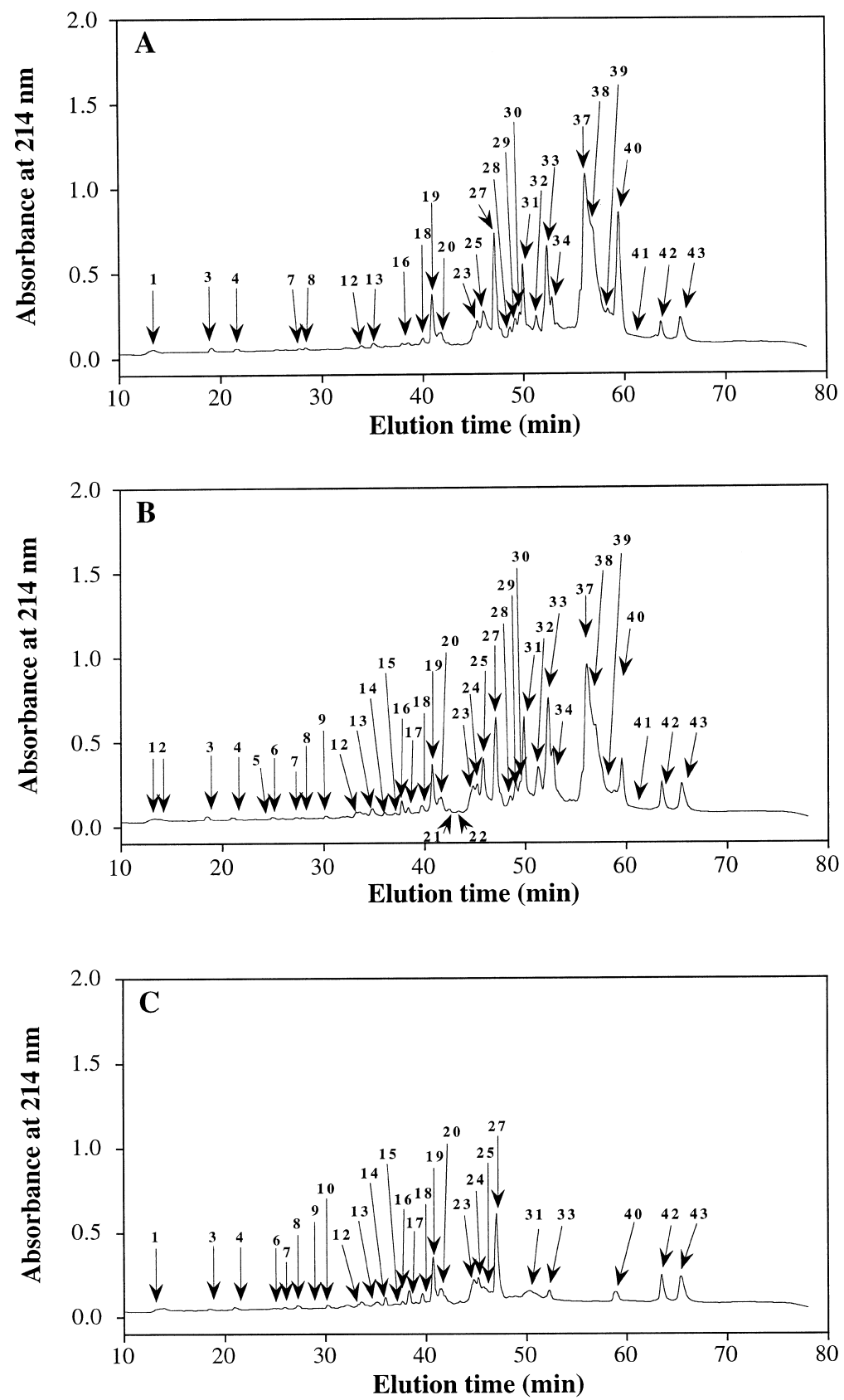

a

Figure 2 RP-HPLC profiles of $\mathrm{pH}$ 4.6-soluble peptides from ovine Na-caseinate (a) and caprine Na-caseinate (b) hydrolyzed for $12 \mathrm{~h}$ by extracts of $C$. cardunculus at pH 6.5 (A), pH 5.5 (B) and pH 5.2 with $5 \%(w / v) ~ N a C l ~(C)$

extensive degradation than ovine $\mathrm{Na}$-caseinate under the same conditions ( $\mathrm{pH} 6.5$ and $\mathrm{pH} 5.5) ; \beta$-casein was completely degraded at $\mathrm{pH} 6.5$ by $3 \mathrm{~h}$ whereas complete degradation was observed by $1 \mathrm{~h}$ at $\mathrm{pH}$ 5.5. Although $\alpha_{\mathrm{s}}$-caseins were not completely broken down even after $6 \mathrm{~h}$ at $\mathrm{pH} 5.2$ in the presence of $5 \%(\mathrm{w} / \mathrm{v}) \mathrm{NaCl}$ (Figures $1 a$ and $1 b$, lanes 10-13), $\alpha_{\mathrm{s}}$-caseins were hydrolyzed faster than $\beta$-caseins in ovine and caprine $\mathrm{Na}$-caseinates.

Under all conditions tested, $\beta$-casein in ovine and caprine $\mathrm{Na}$-caseinates was hydrolyzed by cardosins to yield a pair of bands of higher electrophoretic mobility, comparable to that of bovine $\beta$-I-casein. This is in agreement with previous reports pertaining to ovine casein hydrolyzed by calf chymosin. ${ }^{21}$ Bovine and ovine $\beta$-caseins have very similar amino acid sequences. The cleavage sites are probably conserved; the corresponding bonds in ovine $\beta$-casein susceptible to chymosin are Leu190-Tyr191 and Ala187Phe188. ${ }^{21}$ In bovine and ovine milk cheeses, $\beta$-caseins $\left(\beta_{1}\right.$ and $\beta_{2}$-casein) were degraded to about the same extent (approximately 33\%), but in caprine milk cheeses $\beta$-casein was degraded to a greater extent (approximately 44\%) by proteinases of $C$. cardunculus. ${ }^{27}$ The bonds in bovine 

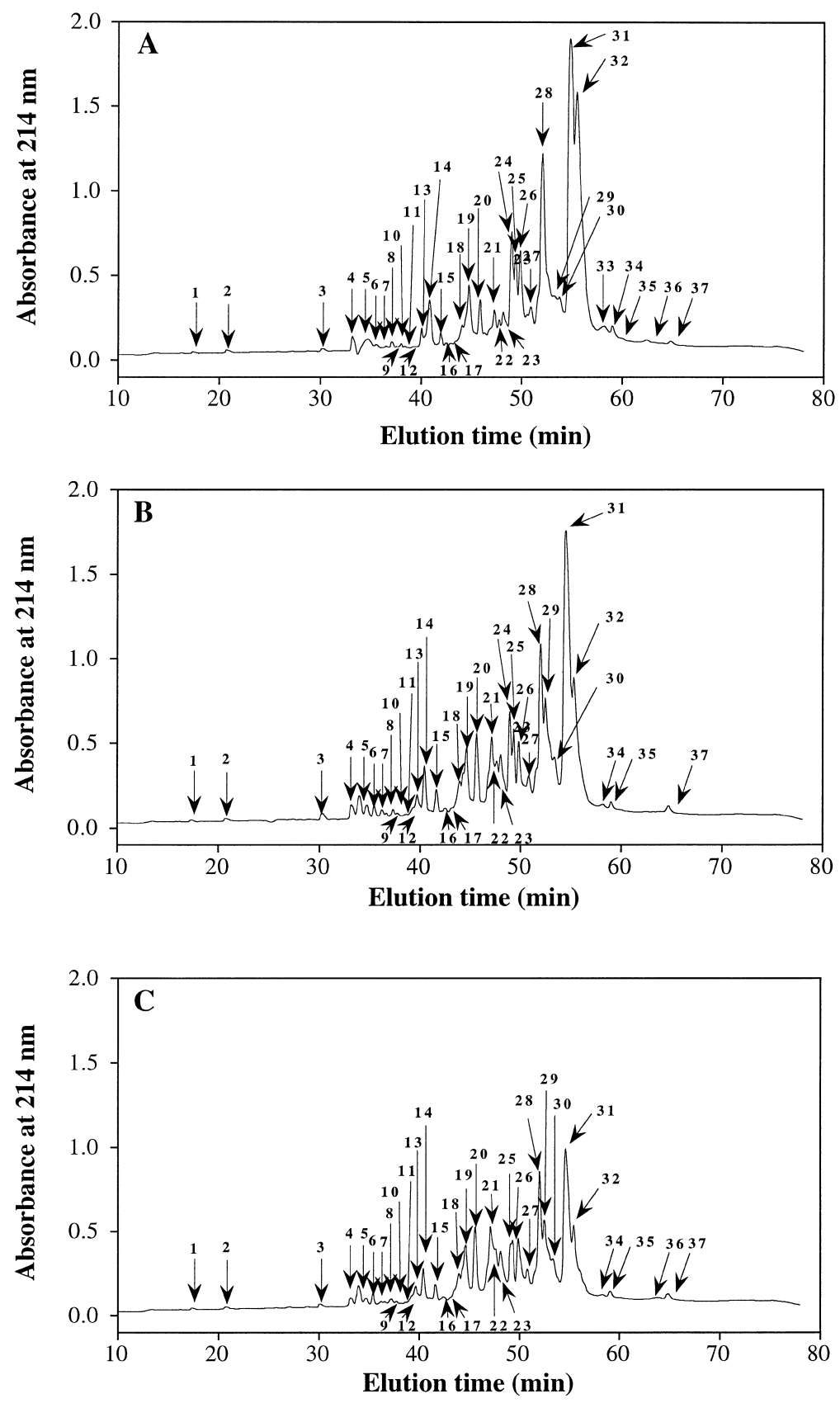

b

Figure 2 Continued

$\beta$-casein most susceptible to action by chymosin and proteinases from flowers of C. cardunculus are Leu192-Tyr193 and Ala189-Phe190, ${ }^{9,28}$ the hydrolysis of which yields $\beta$-I-casein. ${ }^{28}$ In studies of proteolysis of caprine $\beta$-casein by calf rennet, Marcos et al. ${ }^{29}$ for several varieties of cheeses and Carretero et al. ${ }^{30}$ for Montsec cheese, the existence of bands accounted for by $\beta$-I- and $\beta$-II-caseins was reported. Ovine and caprine $\alpha_{\mathrm{s}}$-caseins were hydrolyzed initially to a set of bands of higher electrophoretic mobility which may correspond to bovine $\alpha_{\mathrm{s} 1}$-I-casein. Two bands with greater electrophoretic mobility than the $\alpha_{\mathrm{s} 1}$-I-caseins, tentatively denoted as A, were apparent at $\mathrm{pH} 6.5$ and 5.5 after $1 \mathrm{~h}$ of hydrolysis in ovine Na-caseinate, and at $\mathrm{pH} 6.5,5.5$ and 5.2 with $5 \%(\mathrm{w} / \mathrm{v}) \mathrm{NaCl}$ after $1 \mathrm{~h}$ of hydrolysis in caprine $\mathrm{Na}$-caseinate. Such bands are fragments from $\alpha_{\mathrm{s}}$-I-caseins (f 24-*) because they apparently contain the same sequence at the N-terminus. Bands with similar electrophoretic mobility and the same corresponding $\mathrm{N}$-terminal sequence were found in solutions of bovine $\alpha_{\mathrm{s} 1}$-casein when incubated with extracts from flowers of $C$. cardunculus. $^{28}$ Further degradation products with higher electrophoretic mobility and poorly stained (short or medium peptides) could be seen but were not well resolved due to limitations of the analytical techniques employed. 


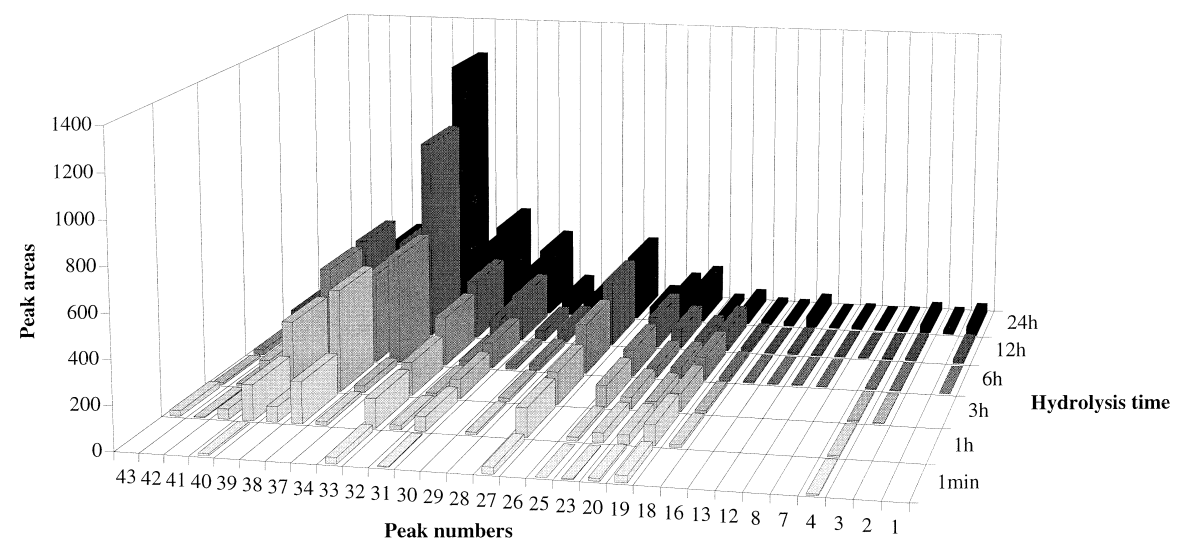

B

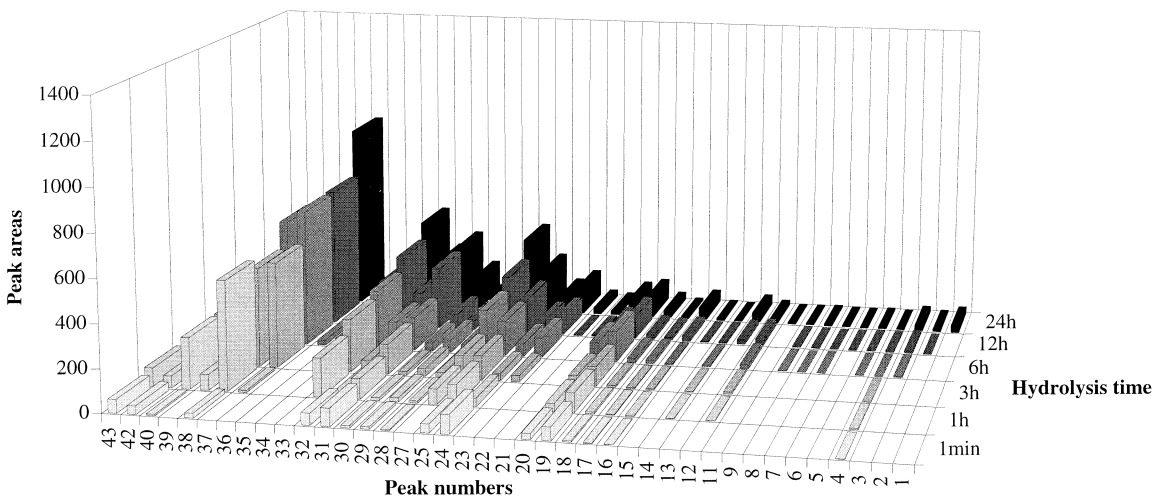

$\mathrm{C}$

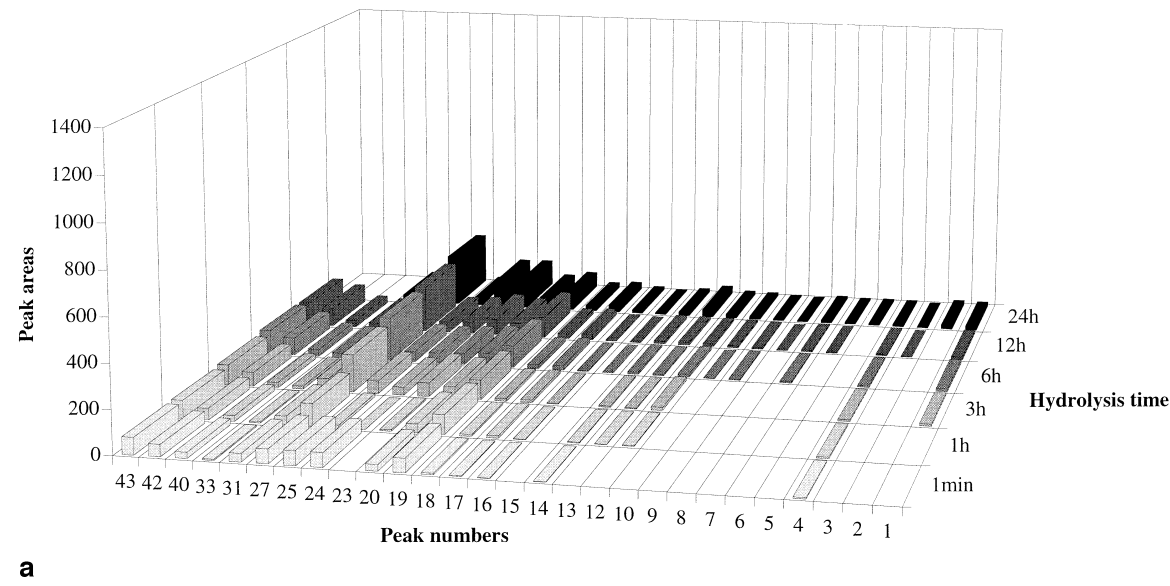

Figure 3 Changes in the area of the RP-HPLC peaks representing the major peptides produced by hydrolysis of ovine Na-caseinate (a) and caprine $\mathrm{Na}$-caseinate (b) catalyzed by extracts of $C$. cardunculus at $30^{\circ} \mathrm{C}$, and $\mathrm{pH} 6.5(\mathrm{~A}), \mathrm{pH} 5.5(\mathrm{~B})$ and $\mathrm{pH} 5.2 \mathrm{with} 5 \%(\mathrm{w} / \mathrm{v}) \mathrm{NaCl}$ (C) for various times

Proteolysis of $\beta$-casein and $\alpha_{\mathrm{s}}$-caseins in ovine and, to a lesser extent, in caprine $\mathrm{Na}$-caseinates (Figures $1 a$ and $1 b$ ) by extracts of $C$. cardunculus was reduced in the presence of $5 \%(\mathrm{w} / \mathrm{v}) \mathrm{NaCl}$ at $\mathrm{pH} 5.2$. $\mathrm{Sousa}^{28}$ reported that proteol- ysis of bovine $\beta$-casein by extracts of $C$. cardunculus at $\mathrm{pH}$ 6.5 was increasingly inhibited as $\mathrm{NaCl}$ concentration was increased up to $20 \%$. It is also known that proteolysis of bovine $\beta$-casein is dependent on $\mathrm{pH}$, ionic strength and 

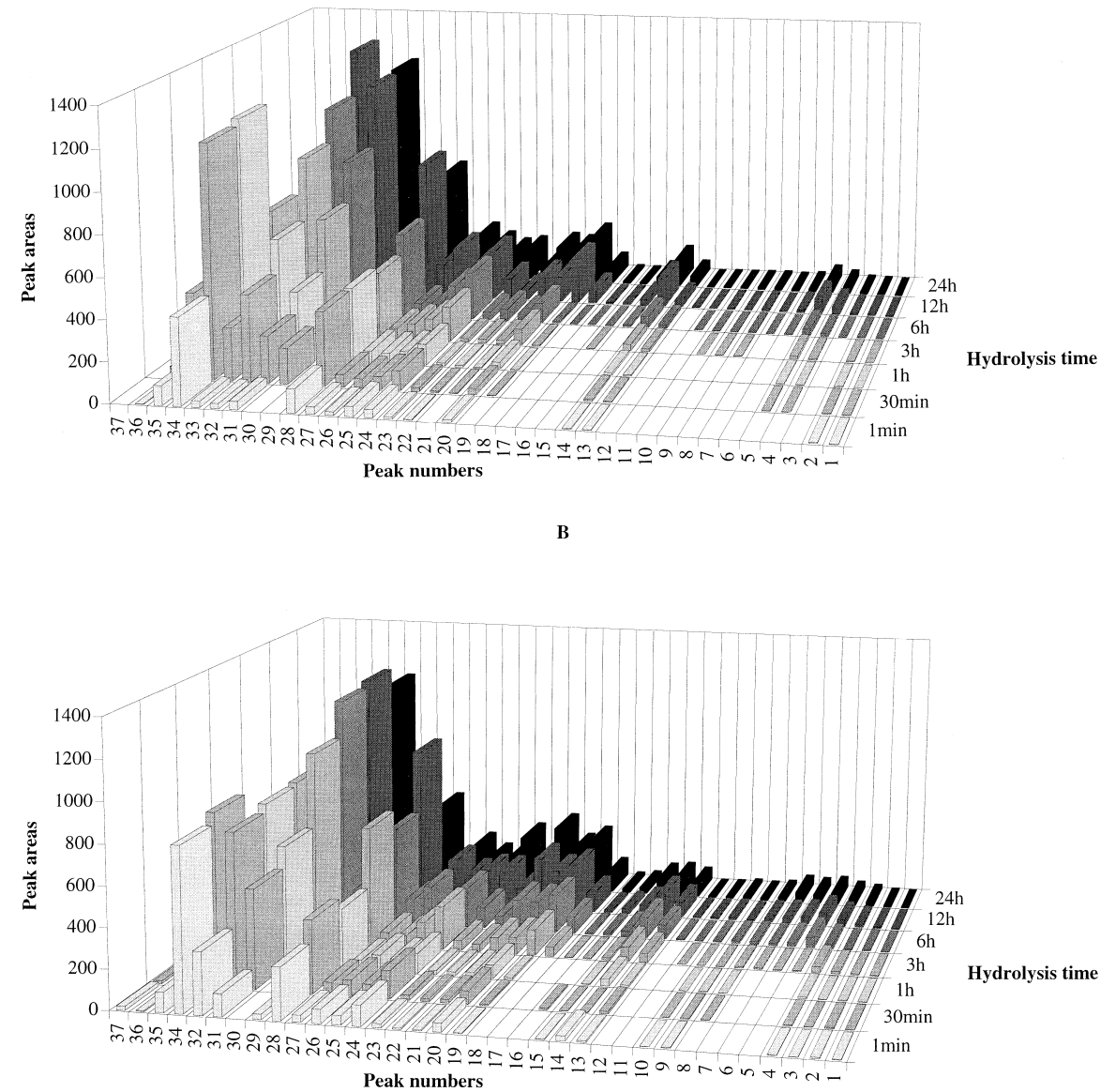

C

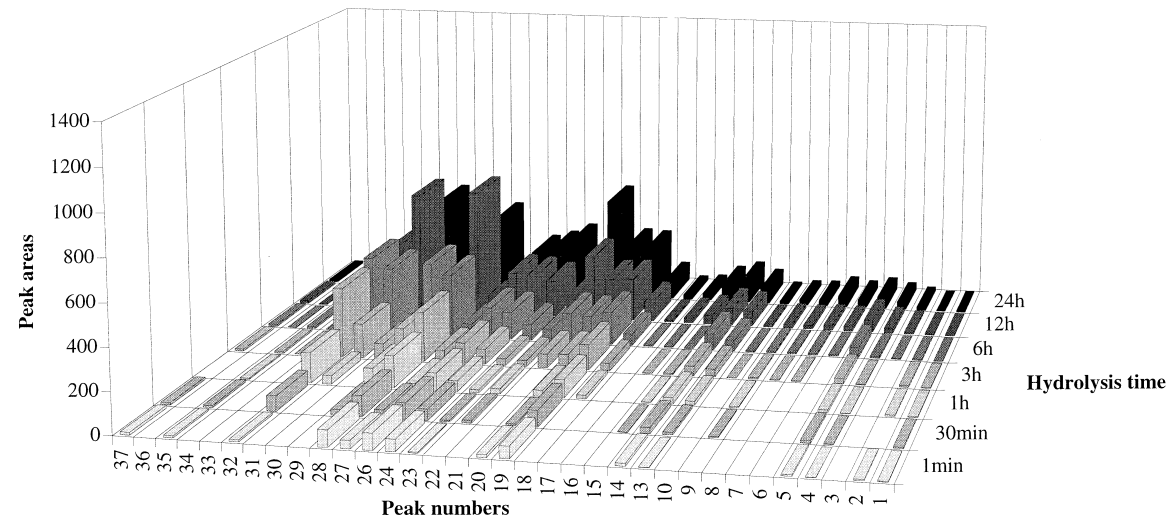

b

Figure 3 Continued

temperature. ${ }^{31}$ Optimum formation of the bovine $\beta$-casein peptides $\beta$-I, $\beta$-II and $\beta$-III by calf chymosin occurs at $\mathrm{pH}$ 6.4, 4.6 and below 4.6, respectively ${ }^{32,33}$; however, Mulvihill and $\mathrm{Fox}^{33}$ claimed that inhibition decreased as $\mathrm{pH}$ was decreased from 7.0 to 4.6. $\beta$-III-casein was not produced in the presence of $2.5 \% \mathrm{NaCl}$ at $\mathrm{pH}$ values below 3.4, but other peptides (e.g., $\beta$-IV-casein and $\beta-V$-casein) were formed under these conditions ( $\beta$-IV-casein was also produced in the absence of $\mathrm{NaCl}$ at $\mathrm{pH} 3.4$ but only at high enzyme/ substrate ratios). Trujillo et al. ${ }^{34}$ found that caprine $\beta-\mathrm{I}-$ 
casein was produced by calf rennet at all $\mathrm{pH}$ values and the corresponding electrophoretic band increased in intensity as $\mathrm{pH}$ was increased. At low $\mathrm{pH}$ values (i.e., not above 4.6), the polypeptide $\beta$-II-casein was the main breakdown product detected and $\beta$-III-casein was not detected at all at any $\mathrm{pH}$ value in the presence of $5 \% \mathrm{NaCl}$. Although definitive evidence is lacking, it has been suggested that $\mathrm{NaCl}$ exerts an influence on the hydrolysis of $\beta$-casein via modification (folding or aggregation) of the substrate rather than of the enzyme. ${ }^{33}$ Less marked influence of $\mathrm{NaCl}$ on proteolysis of bovine $\alpha_{\mathrm{s}}$-caseins by extracts of $C$. cardunculus and by chymosin $^{28}$ supports this view.

The RP-HPLC peptide profiles in the $\mathrm{pH}$ 4.6-soluble fraction of ovine and caprine Na-caseinate hydrolyzed during $12 \mathrm{~h}$ at $30^{\circ} \mathrm{C}$ and $\mathrm{pH} 6.5, \mathrm{pH} 5.5$ or $\mathrm{pH} 5.2$ with $5 \%$ $(w / v) ~ N a C l$ are shown in Figures $2 a$ and $2 b$. The peptide profiles in the $\mathrm{pH} 4.6$-soluble fraction of ovine caseinate were virtually similar to those of caprine caseinate after 1 min of hydrolysis (data not shown), but after $12 \mathrm{~h}$ of hydrolysis, caprine caseinate (Figure $2 b$ ) exhibited a higher number (except at $\mathrm{pH}$ 5.5) and a higher concentration of peptides than ovine caseinate (Figure $2 a$ ). This observation may be due to changes in specificity of cardosins on ovine and caprine milk caseins under different ionic strength conditions. Despite the fact that caprine caseinate showed a higher concentration of peptides at $\mathrm{pH} 6.5$ and $\mathrm{pH} 5.5$ than at pH 5.2 with $5 \% \mathrm{NaCl}$ (Figure $2 b$ ), the number of peptides produced in caprine caseinate was not too different from that in ovine caseinate. The isolated peptides were sequenced by the Edman procedure from their N-terminus in an attempt to identify them. Ovine $\kappa$-casein was cleaved by cardosins at Phe105-Met106 (peptide 19) whereas caprine к-casein was cleaved by cardosins at Lys116-Thr117 (peptide 14). In bovine $\kappa$-casein, the most susceptible bond was Phe105-Met $106^{4}$ and it was also shown that such cleavage was able to induce milk clotting as typically happens with acid proteinases. The $\mathrm{N}$-terminal sequences of the peptides designated as 33 [ $\beta$-(f191-*)], 37 [ $\beta$-(f1-*)], 38 [ $\beta$-(f128-*)] and $40\left[\beta-\left(\mathrm{f} 128-^{*}\right)\right]\left[\beta-\left(\mathrm{f} 191-^{*}\right)\right]$ (Figure $2 a$ ) indicated that ovine $\beta$-casein was cleaved by cardosins at bonds Leu-190Tyr191 and Leu127-Thr128, so possible fragments formed are $\beta$-(f1/127), $\beta$-(f128/192), $\beta$-(f128/207) and $\beta$-(f191/ 207); cardosins showed, on the other hand, a $\beta$-(f191/207) broader specificity toward caprine $\beta$-casein, such as at bonds Glu100-Thr101, Leu127-Thr128, Pro136-Leu137, and Leu192-Tyr193 as indicated by the peptides designated as Leu190-Tyr191 19 [ $\beta$-(f137-*)], 20 [ $\beta$-(f128-*)], 28

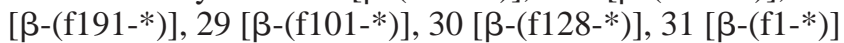
and $32\left[\beta-\left(\mathrm{f} 128-^{*}\right)\right]$ (Figure $\left.2 b\right)$. Chymosin cleaves bovine $\beta$-casein in solution at seven sites which, in decreasing order of rate of attack, are Leu192-Tyr193, Ala189-Phe190, Leu165-Ser166, Gln167-Ser168, Leu163-Ser164, Leu139Leu140 and Leu127-Thr128 (Visser and Slangen, 1977). Under the experimental conditions used by Charles and Ribadeau-Dumas (1984), only the bonds Ala189-Phe190 and Leu192-Tyr193 of bovine $\beta$-casein can be cleaved. Cardosins cleave six bonds over a similar time frame and the relative susceptibility to attack is, in decreasing order, Leu192-Tyr193, Leu191-Leu192, Leu165-Ser166, Phe190Leu191, Ala189-Phe190 and Leu127-Thr128. ${ }^{35}$ Cardosins thus seem to cleave more bonds than chymosin in the bulky, hydrophobic segment Ala189-Phe-Leu-Leu-Tyr193 of bovine $\beta$-casein.

The $\mathrm{N}$-terminal sequence of ovine and caprine $\alpha_{\mathrm{s} 1}$-casein was identified in peptides designated as 27 (Figure $2 a$ ) and 19 (Figure 2b), respectively, as complementary to the peptide associated with the band identified in urea-PAGE as $\alpha_{\mathrm{s}}$-I-casein (Figures $1 a$ and $1 b$ ); hence, the bond cleaved in $\alpha_{\mathrm{s} 1}$-casein was likely Phe23-Val24. Caprine $\alpha_{\mathrm{s} 1}$-casein was cleaved by cardosins at the bonds Phe23-Val24, Trp164Tyr165 and Tyr173-Thr174 as derived from the N-terminal sequences of peptides $24\left[\alpha_{\mathrm{s} 1}-(\mathrm{f} 165-*)\right], 28\left[\alpha_{\mathrm{s} 1}-(\mathrm{f} 24-*)\right]$ and $28\left[\alpha_{\mathrm{s} 1}-(\mathrm{f} 174-*)\right]$ (Figure $2 b$ ). The most susceptible bond to the action of chymosin and cardosins in bovine $\alpha_{\mathrm{s} 1}$-casein is Phe23-Phe24. ${ }^{9,28}$ Its hydrolysis yields $\alpha_{\mathrm{s} 1}$-(f123 ) and (f24-199); ${ }^{22}$ the corresponding susceptible bond in ovine $\alpha_{\mathrm{s}}$-casein with respect to chymosin ${ }^{21}$ and to cardosins is Phe23-Val24, so the electrophoretic band designated as $\alpha_{\mathrm{s} 1}$-I-casein in ovine and caprine caseins (Figures $1 a$ and $1 b$ ) is probably the peptide Val24-Trp199. Macedo et al..$^{35}$ reported that cardosins can, in addition, cleave the eight bonds Tyr153-Tyr154, Trp164-Tyr165, Tyr165-Tyr166, Tyr166-Val167, Phe145-Tyr146, Leu149-Phe150, Leu156Asp157 and Ala163-Trp164 whereas chymosin can only cleave the Phe23-Phe24 bond of bovine $\alpha_{\mathrm{s} 1}$-casein. McSweeney et al..$^{22}$ identified at $\mathrm{pH} 6.5$ and $5 \% \mathrm{NaCl}$ the following seven cleavage sites of bovine $\alpha_{\mathrm{s} 1}$-casein by chymosin: Phe28-Pro29, Leu40-Ser41, Leu149-Phe150, Phe153-Tyr154, Leu156-Asp157, Tyr159-Pro160 and Trp164-Tyr165. These peptide bonds were also cleaved at $\mathrm{pH} 5.2$ in the presence of $5 \% \mathrm{NaCl}$. In addition, Leu11Pro12, Phe32-Gly33, Leu101-Lys102, Leu142-Ala143 and Phe179-Ser180 could also be cleaved. Five of these bonds were also cleaved by cardosins at $\mathrm{pH} 6.5,{ }^{22}$ i.e., Phe23Phe24, Leu149-Phe150, Phe153-Tyr154, Leu156-Asp157 and Trp164-Tyr165, but cardosins could not cleave the two bonds containing a prolyl residue at the C-terminal side.

Ovine $\alpha_{\mathrm{s} 2}$-casein was cleaved by cardosins at Phe88Tyr89 as derived from the N-terminal sequence of the peptide denoted as $31\left[\alpha_{\mathrm{s2}}-(\mathrm{f} 89-*)\right]$ (Figure $\left.2 a\right)$, and caprine $\alpha_{\mathrm{s} 2}$-casein was cleaved by cardosins at Ser9-Ser10, Phe88Tyr89 and Tyr179-Leu180, thus leading to peptides 19 $\left[\alpha_{\mathrm{s} 2}-(\mathrm{f} 180-*)\right], 20\left[\alpha_{\mathrm{s} 2}-(\mathrm{f} 89-*)\right], 25\left[\alpha_{\mathrm{s} 2}-(\mathrm{f} 89-*)\right]$ and 28 $\left[\alpha_{\mathrm{s} 2}-(\mathrm{f} 10-*)\right]$ (Figure $2 b$ ); in bovine $\alpha_{\mathrm{s} 2}$-casein, cardosins catalyzed the hydrolysis of two peptide bonds between rather hydrophobic amino acids (such as Phe88-Tyr89 and Tyr95-Leu96), thus releasing the heptapeptide Tyr89Tyr95. ${ }^{35}$ Grappin et al. claimed that bovine $\alpha_{\mathrm{s} 2}$-casein was resistant to catalytic action by chymosin, but McSweeney et $a l$. argued that chymosin could act upon both Phe88-Tyr89 and Tyr95-Leu96.

Changes in the relative peak area of the major peptides produced by cardosins after $1 \mathrm{~min}, 1 \mathrm{~h}, 3 \mathrm{~h}, 6 \mathrm{~h}, 12 \mathrm{~h}$ and $24 \mathrm{~h}$ are represented in Figures $3 a$ and $3 b$ for ovine and caprine caseinates. The peptide profiles of the ovine caseinate hydrolysates were similar to one another, although those peptide peaks denoted as 26 and 41 were present only at $\mathrm{pH} 6.5$, and those peptide peaks denoted as 11, 21, 22, 35 and 36 were present only at $\mathrm{pH} 5.5$. At $\mathrm{pH} 6.5$ after $1 \mathrm{~min}$ of hydrolysis (Figure 3a-A), the primary peptides apparent were those denoted as $4,19,20,23,25,27,31,33$ and 40. The peptides denoted as $23,27\left[\alpha_{\mathrm{s} 1^{-}}\left(\mathrm{f} 1-^{*}\right)\right], 31\left[\alpha_{\mathrm{s} 2^{-}}\right.$ 
(f89-*)] and 33 [ $\beta$-(f191-*)] showed the highest specific formation rates, such as $8.02,4.77,1.31 \times 10$ and $1.30 \times$ $10 \mathrm{UA}$ (units of absorbance) $\mathrm{min}^{-1} \mathrm{RU}^{-1}$, respectively. At the same $\mathrm{pH}$ but after $1 \mathrm{~h}$ of hydrolysis (Figure $3 a-A$ ), the secondary peptides denoted as 32,37 [ $\beta$-(f1-*)] and 38 $[\beta-(\mathrm{f} 128-*)]$ were those that exibited the highest formation rates, such as $1.04 \times 10,4.70 \times 10$ and $1.05 \times 10 \mathrm{UA}$ $\mathrm{min}^{-1} \mathrm{RU}^{-1}$, respectively. They did not reach a plateau during the whole period of study $(24 \mathrm{~h})$. At pH 5.5 after 1 min of hydrolysis (Figure 3a-B), the primary peptides apparent were those denoted as 4, 16-20, 24, 25, 28-32, 38, 40, 42 and 43. Peptides denoted as 16, 18, 20, 24, 25, 29, 30 and 32 displayed the highest formation rates, such as 3.21, $1.42,2.63,1.57,3.79,2.49,7.96$ and $6.45 \mathrm{UA} \mathrm{min}^{-1} \mathrm{RU}^{-1}$. The secondary peptides denoted as 27, 33 and 37 (Figure $3 a-B$ ) showed the highest formation rates by $1 \mathrm{~h}$, such as $8.58,7.30$ and $2.19 \times 10 \mathrm{UA} \mathrm{min}^{-1} \mathrm{RU}^{-1}$, respectively. The peptides produced at $\mathrm{pH} 5.2$ with $5 \%$ (w/v) $\mathrm{NaCl}$ after 1 min of hydrolysis (Figure $3 a-C$ ) were, with the exception of peptide denoted as 10 , also produced at either $\mathrm{pH} 6.5$ or $\mathrm{pH}$ 5.5. The major primary and secondary peptides were those denoted as 24 and 23 , respectively, with formation rates of 4.75 and $3.38 \mathrm{UA} \mathrm{min}^{-1} \mathrm{RU}^{-1}$, respectively. The peptide profiles of the caprine hydrolysates at $\mathrm{pHs} 6.5,5.5$ and 5.2 with $5 \%(\mathrm{w} / \mathrm{v}) \mathrm{NaCl}$ (Figure $3 b, A-C$ ) had a number of peptides in common. Hydrolysates from caprine caseinate produced at $\mathrm{pH} 6.5$ after 1 min (Figure $3 b-A$ ) included as primary peptides those denoted as 1,2, 13, 14, 20, 22-28 and 31-36. The highest formation rates were observed for those peptides denoted as $20\left[\beta-(\mathrm{f} 128-*)+\alpha_{\mathrm{s} 2}-(\mathrm{f} 89-*)\right], 24$ $\left[\alpha_{\mathrm{s} 1}-(\mathrm{f} 165-*)\right], 26,28\left[\alpha_{\mathrm{s} 1}-(\mathrm{f} 24-*)+\alpha_{\mathrm{s} 1}-(\mathrm{f} 174-*)+\right.$ $\beta$-(f191-*) $+\alpha_{\mathrm{s} 2}$-(f10-*)], $31[\beta$-(f1-*)] and 32 [ $\beta$-(f128$*)$, such as $7.87,4.85,9.99,2.20 \times 10,5.37 \times 10$ and $4.13 \times 10 \mathrm{UA} \mathrm{min}^{-1} \mathrm{RU}^{-1}$, respectively. At $\mathrm{pH} 5.5$ after 1 min of hydrolysis (Figure $3 b-A$ ), the primary peptides were those denoted as $1-4,9,10,13-15,19-29,31,32$ and 34-37 whereas the ones that showed the highest formation rates were $19-23,28,29$ and 31 , such as $1.34 \times 10,9.18$, $1.64 \times 10,7.86,1.26 \times 10,8.37,1.14 \times 10$ and $4.85 \times 10$ $\mathrm{UA} \min ^{-1} \mathrm{RU}^{-1}$, respectively. The secondary peptides produced from caprine caseinate at $\mathrm{pH} 6.5$ that showed the highest formation rates were $19\left[\alpha_{\mathrm{s} 1}-(\mathrm{f} 1-*)+\alpha_{\mathrm{s} 2}(\mathrm{f} 180-*)\right.$ $+\beta$-(f137-*)], 21 and 29 [ $\beta$-(f101-*)], such as $1.18 \times 10$, 8.95 and $1.97 \times 10 \mathrm{UA} \mathrm{min}^{-1} \mathrm{RU}^{-1}$, respectively, but at pH 5.5 no secondary peptide was found that exhibited a significant rate of formation. All peptides produced at $\mathrm{pH}$ 5.2 and $5 \%(\mathrm{w} / \mathrm{v}) \mathrm{NaCl}($ Figure $3 b-C)$ were also produced either at $\mathrm{pH} 6.5$ or $\mathrm{pH}$ 5.5. The major primary and secondary peptides were denoted as 28 and 21 with corresponding formation rates of $1.48 \times 10$ and $2.44 \times 10 \mathrm{UA} \mathrm{min}^{-1}$ $\mathrm{RU}^{-1}$, respectively.

\section{Acknowledgments}

Financial support for author Sousa was provided by a Ph.D. fellowship issued by program PRAXIS XXI (BD-2763/93), Portugal. Partial funding for this research work was provided through grants within program PRAXIS XXI (project IMPACTO: Investigação dirigida ao melhoramento do processo de produção de queijo da Serra por integracão de abordagens científicas e tecnológicas), Portugal and
PAMAF-IED (project PROTOLACTIS: produção, por tecnologias optimizadas, de lacticínios tradicionais certificados), Portugal.

\section{References}

1. Macedo, A., Malcata, F. X. and Oliveira, J. C. The technology, chemistry and microbiology of Serra cheese: A review. J. Dairy Sci. 1993, 76, 1725-1739

2. Faro, C. J., Alface, J. S. and Pires, E. V. Purification of a protease from the flowers of Cynara cardunculus L. Ciên. Biol. 1987, 12, 201

3. Faro, C. J., Moir, A. J. and Pires, E. V. Specificity of a milk-clotting enzyme extracted from the thistle Cynara cardunculus L.: action on oxidized insulin and к-casein. Biotecnol. Lett. 1992, 14, 841-846

4. Macedo, I., Faro, C. J. and Pires, E. M. Specificity and kinetics of the milk-clotting enzyme from cardoon (Cynara cardunculus L.) toward bovine к-casein. J. Agri. Food Chem. 1993, 41, 1537-1547

5. Heimgartener, U., Pietrzak, M., Geertsen, R., Brodelius, P., Silva Figueiredo, A. C., and Pais, M. S. S. Purification and partial characterization of milk clotting proteases from flowers of Cynara cardunculus. Phytochemistry 1990, 29, 1405-1410

6. Campos, R., Guerra, R., Aguiar, M., Ventura, O. and Camacho, L. Chemical characterization of proteases extracted from wild thistle (Cynara cardunculus.). Food Chem. 1990, 35, 89-97

7. Faro, C. Purificação e caracterização físico-química da protease de Cynara cardunculus L. Ph.D. thesis, Universidade de Coimbra, Portugal, 1991

8. Cordeiro, M. C., Jakob, E., Puhan, Z., Pais, M. S. and Brodelius, P. E. Milk clotting and proteolytic activities of purified cynarases from Cynara cardunculus - a comparison to chymosin. Milchwissenschaft 1992, 47, 683-700

9. Macedo, I. Especificidade caseinolítica da protease de Cynara cardunculus L. Ph.D. thesis, Universidade de Coimbra, Portugal, 1993

10. Pires, E., Faro, C., Macedo, I., Esteves, C., Morgado, J., Veríssimo, P., Pereira, D. and Gomes, D. Flor de cardo versus quimosina no fabrico de queijos artesanais. Química 1994, 54, 66-68

11. Faro, C. J., Veríssimo, P., Lin, Y., Tang, J. and Pires, E. V. In: Aspartic proteinases: Structure, Function, Biology and Biomedical Implications. Takahashi, K. (ed.). Plenum Press, New York, USA. 1995, 373-377

12. Veríssimo, P., Faro, C., Moir, A. J., Lin, Y., Tang, J. and Pires, E. Purification, characterization and partial amino acid sequencing of two new aspartic proteinases from fresh flowers of Cynara cardunculus L. Eur. J. Biochem. 1996, 235, 762-768

13. Veríssimo, P., Esteves, C., Faro, C. and Pires, E. The vegetable rennet of Cynara cardunculus L. contains two proteinases with chymosin and pepsin-like specificities. Biotechnol. Lett. 1995, 17, 621-626

14. Ramalho-Santos, M., Veríssimo, P., Faro, C. and Pires, E. Action on bovine $\alpha_{\mathrm{s} 1}$-casein of cardosins $\mathrm{A}$ and $\mathrm{B}$, aspartic proteinases from the flowers of the cardoon Cynra cardunculus L. Biochim. Biophys. Acta 1996, 1297, 83-89

15. Fox, P. F. Influence of aggregation on the susceptibility of casein to proteolysis. J. Dairy Res. 1970, 37, 173-180

16. Richardson, B. C. and Mercier, J. C. The primary structure of the ovine $\beta$-caseins. Eur. J. Biochem. 1979, 99, 285-297

17. Chianese, L., Garro, G., Ferranti, P., Malorni, A., Addeo, F., Rabasco, A., and Pons, P. M. Discrete phosphorylation generates the electrophoretic heterogeneity of ovine $\beta$-casein. J. Dairy Res. 1995 , 62, 89-100

18. Richardson, B. C. and Creamer, L. K. Comparative micelle structure. V. The isolation and characterization of the major ovine caseins. N. Z. J. Dairy Sci. Technol. 1976, 11, 46-53

19. Boisnard, M. and Petrissant, G. Complete sequence of ovine-casein messenger RNA. Biochimie 1985, 67, 1043-1051

20. Mercier, J. C., Gaye, P., Soulier, S., Hue-Delahaie, D. and Vilotte, J. L. Construction and identification of recombinant plasmids carrying cDNAs coding for ovine $\alpha_{\mathrm{s} 1}, \alpha_{\mathrm{s} 2^{-}}, \beta$, к-casein and $\beta$-lactoglobulin. Nucleotide sequence of $\alpha_{\mathrm{s} 1}$-casein cDNA. Biochimie 1985, 67, 959-971

21. Whyte, N. H. Proteolysis of bovine and ovine caseins by lamb and 
calf chymosin. M.Sc. thesis, National University of Ireland, Cork, Ireland, 1995

22. McSweeney, P. L. H., Olson, N. F., Fox, P. F., Healy, A., and Hojrup, P. Proteolytic specificity of chymosin on bovine $\alpha_{s 1}$-casein. J. Dairy Res. 1993, 60, 401-412

23. Shalabi, S. I. and Fox, P. F. Electrophoretic analysis of cheese: Comparison of methods. Ir. J. Food Sci. Technol. 1987, 11, 135-151

24. Blakesley, R. W. And Boezi J. A. A new staining technique for proteins in polyacrylamide gels using Coomassie Brillant Blue G-250. Anal. Biochem. 1977, 82, 580-581

25. McGann, T. C. A., Mathiassen, A. and O'Connell, J. A. Applications of the Pro-Milk Mk II. Part III. Rapid estimation of casein in milk and protein in whey. Lab. Prac. 1972, 21, 628-631, 650

26. Singh, T. K., Fox, P. F. and Healy, A. Water-soluble peptides in Cheddar cheese: isolation and identification of peptides in the diafiltration retentate of the water-soluble fraction. J. Dairy Res. 1995, 62, 629-640

27. Sousa, M. J. and Malcata F. X. Proteolysis in bovine, ovine and caprine cheeses manufactured with a plant rennet (Cynara cardunculus), Proceedings of "X Congresso Nacional de Bioquímica", Braga, Portugal: October 31-November 2, 1996, pp 86, P9-29

28. Sousa, M. J. C. F. Plant rennet substitute from flowers of Cynara cardunculus. M.Sc. thesis, National University of Ireland, Cork, Ireland, 1993

29. Marcos, A., Esteban, M. A., León, F. and Fernández-Salguero, J. Electrophoretic patterns of European cheeses: Comparison and quantification. J. Dairy Sci. 1979, 62, 892-900

30. Carretero, C., Trujillo, A. J., Mor-Mur, M. and Guamis, B. Electrophoretic study of casein breakdown during ripening of goat's milk cheese. J. Agric. Food Chem. 1994, 421, 1456-16550
31. Dalgleish, D. G. The enzymatic coagulation of milk. In: Developments in Dairy Chemistry Vol 1 (Fox, P. F., Ed). Applied Science Publishers, London, 1992, 157-187

32. Guiney, J. A. A study of various factors influencing $\beta$-casein hydrolysis by rennet. M. Sc. thesis, National University of Ireland, Cork, 1973

33. Mulvihill, D. M. and Fox, P. F. Proteolysis of bovine $\beta$-casein by chymosin: Influence of $\mathrm{pH}$, urea, and sodium chloride. Ir. J. Food Sci. Technol. 1978, 2, 135-139

34. Trujillo, A. J., Guamis, B. and Carretero, C. J. Proteolysis of goat $\beta$-casein by calf rennet under various factors affecting the cheese ripening process. J. Agric. Food Chem. 1995, 43, 1472-1478

35. Macedo, I., Faro, C. J. and Pires, E. M. Caseinolytic specificity of cardosin, an aspartic protease from the cardoon Cynara cardunculus L.: Action on bovine $\alpha_{\mathrm{s}^{-}}$and $\beta$-casein and comparison with chymosin. J. Agri. Food Chem. 1996, 44, 42-47

36. Andrews, A. T. J. Proteinases in normal bovine milk and their action on caseins. J. Dairy Res. 1983, 50, 45-55

37. Carles, C. and Ribadeau-Dumas, B. Kinetics of action of chymosin (rennin) on some peptide bonds of bovine $\beta$-casein. Bio/Chemistry 1984, 23, 6839-6843

38. Grappin, R., Rank, T. and Olson, N. Primary proteolysis of cheese proteins during ripening. A review. J. Dairy Sci. 1994, 68, 531-540

39. McSweeney, P. L. H., Olson, N. F., Fox, P. F. and Healy, A. Proteolysis of bovine $\alpha_{\mathrm{s} 2}$-casein by chymosin. Z. Lebensm. Unters. Forsch. 1994, 199, 429-432

40. Visser, S. and Slangen, K. J. On the specificity of chymosin (rennin) in its action on bovine $\beta$-casein. Neth. Milk Dairy J. 1977, 31, $16-30$ 